Agro-Science Journal of Tropical Agriculture, Food, Environment and Extension Volume 20 Number 3 (July 2021) pp. 80 - 90

ISSN 1119-7455

\title{
BIO-ENHANCED REMOVAL OF HYDROCARBON CONTENTS FROM SPENT ENGINE OIL CONTAMINATED SOIL USING Staphylococcus aureus AND Bacillus cereus CO-CULTURE
}

\author{
*1, ${ }^{2}$ Adeleye A.O., ${ }^{2}$ Yerima M.B., ${ }^{3}$ Nkereuwem M.E., ${ }^{3}$ Onokebhagbe V.O., \\ ${ }^{4}$ Sadiq I.S., ${ }^{1}$ Amoo A.O., ${ }^{1}$ Bate G.B., ${ }^{2}$ Shiaka G.P. and ${ }^{2}$ Raji M. \\ ${ }^{1}$ Department of Environmental Sciences, Federal University Dutse, Nigeria \\ ${ }^{2}$ Department of Microbiology \& Biotechnology, Federal University Dutse, Nigeria \\ ${ }^{3}$ Department of Soil Science, Federal University Dutse, Nigeria \\ ${ }^{4}$ Department of Chemistry, Federal University Dutse, Nigeria \\ *Corresponding author's email: adeniyi.adeleye@fud.edu.ng
}

\begin{abstract}
The study assessed the removal of total petroleum hydrocarbon (TPH) and polyaromatic hydrocarbons (PAHs) from spent engine oil (SEO) contaminated soil through bioenhancement of bacteria isolated from SEO polluted soil. Sterilized soil was subjected to a three level of SEO contamination before the addition of sterilized biostimulants including powdered cow dung (CD), powdered cocoa pod husk (CPH) and compost (made from fresh CPH and CD). Bacterial inoculum being Staphylococcus aureus and Bacillus cereus coculture $(150 \mathrm{~mL})$ was added to the mixture in polyethylene bags. It was a factorial experiment that was laid out in a completely randomized design (CRD). The TPH and PAHs were estimated in the first day, fifth week and the tenth week that the room incubation lasted. Results generated from the influence of biostimulants on TPH and PAHs degradation potential of the bacterial co-culture showed that degradation of the hydrocarbon contents was significantly enhanced $(p<0.05)$. At the tenth week, compost enhanced the most TPH reductions (315 and $380 \mathrm{mg} \mathrm{kg}^{-1}$ ) compared with other biostimulants on 5\% and 15\% SEO contamination levels, respectively. Compost equally enhanced the most PAHs reductions $\left(48.8,39.6\right.$ and $\left.94.6 \mathrm{mg} \mathrm{kg}^{-1}\right)$ compared with other biostimulants on 5\%,10\% and $15 \%$ SEO contamination levels respectively. However, the quantity of SEO contents degraded was significantly higher in the bioaugmented and biostimulated soil samples compared with the control employed. The technology adopted in this study can be effectively employed for the bioremediation of petroleum hydrocarbon related pollution.
\end{abstract}

Key words: bioremediation, biostimulants, bacterial co-culture, TPH and PAHs

\section{INTRODUCTION}

Increasing demand for petroleum products in the world over has brought a substantial increment in its extraction and final processing (Obi et al., 2016). According to Bhattacharyya and Shekdar (2003), this substantial increment has brought about a huge waste accruable from its usage. Soil pollution attributable to petroleum hydrocarbons can loiter on for so many years thereby affecting the physicochemical quality of the soil in the process (Umoren et al., 2019). The adoption of bioremediation for the removal of hydrocarbon related pollutants in the environment has become popular owing to its promising exploits. Bioremediation technology has attracted positive attention due to its cost effectiveness and environmentally friendly nature (Dinkla et al., 2001). It has been reported in numerous studies that catabolic capabilities of certain hydrocarbonoclastic microorganisms like bacteria, fungi and algae make it possible for them to facilitate the degradation of petroleum hydrocarbons (Dean-Ross et al., 2002; Wang et al., 2011; Maiti et al., 2012; Badr El-Din et al., 2014). These microbes have the required enzymatic capacity that makes possible their utilisation of the pollutant hydrocarbons as their sole sources of carbon and energy (Panda et al., 2013).

In Nigeria, spent engine oil (SEO) has instituted a vital source of pollution owing to its disposal into aquatic and terrestrial ecosystems indiscriminately (Osaigbovo et al., 2013). According to these authors, contamination of unoccupied plots of land and agricultural farmlands with hydrocarbon-based products has become an extensive problem than crude oil pollution particularly in the urban areas. Polyaromatic hydrocarbons (PAHs), which are inseparable from SEO has been documented to have toxic, mutagenic, teratogenic, certain immunological, carcinogenic, reproductive, fetotoxic and genotoxic effects when found in many environmental media (Clemente et al., 2001; Yerima et al., 2013; Umana et al., 2017).

Please cite as: Adeleye A.O., Yerima M.B., Nkereuwem M.E., Onokebhagbe V.O., Sadiq I.S., Amoo A.O., et al. (2021). Bio-enhanced removal of hydrocarbon contents from spent engine oil contaminated soil using Staphylococcus aureus and Bacillus cereus co-culture. Agro-Science, 20 (3), 80-90. DOI: https://dx.doi.org/10.4314/as.v20i3.11 
Due to the established damaging health risks that PAHs can exert on the environment and humans, its complete elimination from environmental media necessitates approaches that are viable and affordable (Adeleye et al., 2020). The adoption of bacterial co-cultures for possible bioremediation of SEO contaminated soil is in line with the reports of Ogunbayo et al. (2012) together with Kawo and Faggo (2017) on the ability of bacterial co-cultures to enhance better and faster degradation of hydrocarbons than individual pure cultures. It is based on these backgrounds that this current study was piloted with a view to assessing the elimination of the hydrocarbon contents of SEO contaminated soil through bioenhancement of Staphylococcus aureus and Bacillus cereus coculture isolated from a typical SEO-polluted soil.

\section{MATERIALS AND METHODS \\ Description of the Study Area}

This study was conducted at the Department of Soil Science, Faculty of Agriculture, Federal University Dutse (Latitude $11^{\circ} 46^{\prime} 39^{\prime \prime}$ North and Longitude $9^{\circ} 20^{\prime} 3^{\prime \prime}$ East) Jigawa State, Nigeria (Adeleye et al., 2020).

\section{Processing of Biostimulants}

All the processed biostimulants: powdered cow dung (CD), powdered cocoa pod husk (CPH) and compost (fresh $\mathrm{CPH}$ and $\mathrm{CD}$ compost) used in this study were derived as earlier reported by Adeleye et al. (2020). Fresh $\mathrm{CPH}$ was cut into smaller pieces less than $5 \mathrm{~cm}$ so as to ensure a surface area suitable for its active decomposition as done by Komolafe et al. (2021).

\section{Soil Collection and Processing}

Soil $(250.0 \mathrm{~kg})$ at the depth of $25.0 \mathrm{~cm}$ that had no history of any form of pollution (Nkereuwem et al., 2020), was collected with the aid of soil auger using grid method of soil sampling from four spots at the Teaching and Research Farm, Department of Soil Science, Federal University Dutse. It was thereafter subjected to air drying with a view to forming a composite sample. As established by Soretire et al. (2017), the bulked soil was sieved with $2.0-\mathrm{mm}$ mesh size. The soil was autoclaved at $121^{\circ} \mathrm{C}$ for $15 \mathrm{~min}$. to expunge extraneous influence of unwanted microbial life. One and a half (1.5) kg of the sterilized soil was then poured into 36 polyethylene bags each. Fresh spent engine oil (SEO) collected from a service pit in Dutse Mechanic Village was added to the bagged soil. Specifically, varying levels of the SEO (75-, 150and $225-\mathrm{mL}$ weight/weight), representing 5, 10 and $15 \%$ contamination levels, respectively were added separately to the bagged soil. The soil-SEO mixtures were exhaustively variegated, and left undisturbed for 14 days for volatilization of the toxic components of the SEO as reported by Abioye et al. (2012) and Agbor et al. (2015).
Isolation and Identification of Bacterial CoCulture Used for Bioaugmentation

The procedures used by Adeleye et al. (2019) were employed for the isolation and identification of the bacteria (Staphylococcus aureus and Bacillus cereus) used as a co-culture for bioaugmentation in this study.

\section{Experimental Design and Biodegradation}

The design was a $4 \times 3$ factorial experiment laid out in completely randomized design (CRD) with three replications. The two factors were: (a) biostimulants at four levels including the control ( $\mathrm{B}_{0}$, having no biostimulant), $\mathrm{B}_{1}$ being compost, $\mathrm{B}_{2}$ being powdered $\mathrm{CPH}$, and $\mathrm{B}_{3}$ being powdered $\mathrm{CD}$; and (b) SEO at three levels of $75(5 \%), 150(10 \%)$ and $225 \mathrm{~mL}(15 \%)$, designated $\mathrm{S}_{1}, \mathrm{~S}_{2}$ and $\mathrm{S}_{3}$, respectively. This experimental layout implies that the bacterial co-culture $(150 \mathrm{~mL})$ in each of the polyethylene bags containing the SEO-polluted soil was bioaugmented, apart from the control that did not receive such bioaugmentation and biostimulation.

All the polyethylene bags were subjected to incubation at room temperature for 70 days (Chorom et al., 2010). As established by Ayotamuno et al. (2006), the contents of each polyethylene bag were tilled twice a week for aeration. Maintenance of moisture content was equally done twice a week by the addition of 6.0 $\mathrm{mL}$ sterile distilled water (Abioye et al., 2012).

\section{Determination of the Physico-Chemical} Properties of Soil and Biostimulants

Following the procedures used by Adeleye et al. (2020), available phosphorous, $\mathrm{pH}$ in water, electrical conductivity (EC), moisture content, total nitrogen, organic carbon, texture and other related properties of the soil and biostimulants were determined.

Determination of Total Petroleum Hydrocarbon and Polycyclic Aromatic Hydrocarbons

Total petroleum hydrocarbon (TPH) and polycyclic aromatic hydrocarbons (PAHs) were determined with the aid of gas chromatograph flame ionization detector (GC-FID) following the United States Environmental Protection Agency (USEPA) 1850C method described by USEPA (2003).

\section{Data Collection and Analysis}

Periodic sampling for the estimations of TPH and PAHs was done at the commencement, 5th week and 10th week of the experiment. All data were subjected to analysis of variance by the procedure of General Linear Model of GenStat Version 17.0. Significant means were separated using Duncan's new multiple range test.

\section{RESULTS}

The physical and chemical properties of the soil and biostimulants are depicted in Table 1. The results obtained from the mechanical analysis of the soil showed it as sandy loam. The total sum of exchangeable bases of the soil, compost, powdered CPH and powdered CD employed in this study recorded 3.51, $221.7,166.15$ and $82.1 \mathrm{cmol} \mathrm{kg}^{-1}$ respectively. 
Table 1: Physicochemical properties of the soil and biostimulants

\begin{tabular}{|c|c|c|c|c|}
\hline Properties & Soil & Powdered CD & Powdered CPH & Compost \\
\hline Ash content $(\%)$ & Nil & 68.80 & 23.00 & 65.00 \\
\hline Available phosphorous $\left(\mathrm{mg} \mathrm{kg}^{-1}\right)$ & 11.02 & 1.20 & 0.08 & 1.48 \\
\hline $\mathrm{pH}_{\text {(water) }}$ & 6.50 & 8.15 & 7.60 & 9.45 \\
\hline Organic carbon $(\%)$ & 0.49 & 41.55 & 33.40 & 48.25 \\
\hline Total nitrogen $(\%)$ & 0.06 & 2.85 & 2.65 & 5.85 \\
\hline Sodium & 0.58 & 0.40 & 0.10 & 0.50 \\
\hline Calcium & 1.82 & 0.20 & 1.60 & 4.80 \\
\hline Magnesium & 0.92 & 1.50 & 2.45 & 3.24 \\
\hline Potassium & 0.19 & 80.00 & 162.00 & 213.16 \\
\hline CEC & 3.51 & 82.10 & 166.15 & 221.70 \\
\hline \multicolumn{5}{|l|}{ Particle size $\left(\mathrm{g} \mathrm{kg}^{-1}\right)$} \\
\hline Textural class & Sandy loam & Nil & Nil & Nil \\
\hline
\end{tabular}

TPH and PAHs Reference Point Concentrations in Different Levels of SEO Contaminated Soil

The varying concentrations of TPH and PAHs in successive levels of SEO contaminated soil before bacterial degradation are depicted in chromatograms shown in Figures 1 and 2. Contaminated soil with 5, 10 and $15 \%$ SEO recorded TPH concentrations of $9,934 \mathrm{mg} \mathrm{kg}^{-1}$, $10,016 \mathrm{mg} \mathrm{kg}^{-1}$ and $10,379 \mathrm{mg} \mathrm{kg}^{-1}$ respectively (Figure 1) having the presence of carbons (C) ranging from $\mathrm{C}_{8}$ to $\mathrm{C}_{40}$. Similarly, contaminated soil with 5, 10 and 15\% SEO recorded PAHs concentrations of $1065.98,1726.59$ and 1865.63 $\mathrm{mg} \mathrm{kg}^{-1}$, respectively (Figure 2).

mVolts

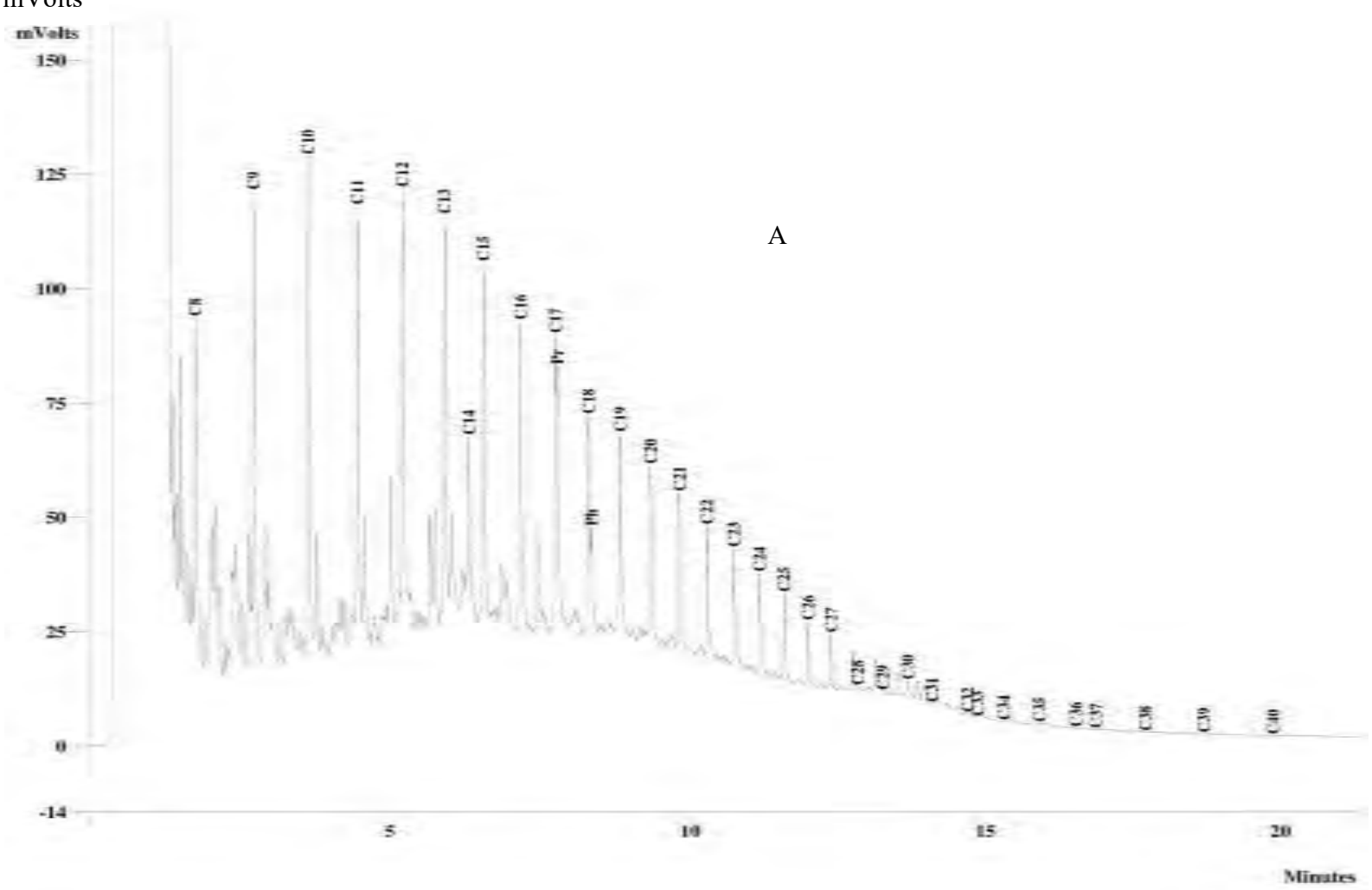

TPH Biodegradation Potential of Staphylococcus aureus and Bacillus cereus Co-Culture

On the TPH degradation potential of $S$. aureus and $B$. cereus co-culture, these biostimulants significantly $(p<0.05)$ enhanced TPH degradation at the 5th week. Compost enhanced the most TPH reductions (836, 560 and 3,507 $\mathrm{mg} \mathrm{kg}^{-1}$ ) compared with other biostimulants used on 5, 10 and $15 \%$ contamination levels of SEO, respectively (Figure 3). Compost sustained this trend at the 10th week as it had the most reductions ( 315 and $380 \mathrm{mg} \mathrm{kg}^{-1}$ ) compared with other biostimulants on 5 and $15 \%$ SEO levels, respectively. However, powdered $\mathrm{CPH}$ showed the most TPH reduction $\left(212 \mathrm{mg} \mathrm{kg}^{-1}\right)$ compared with other biostimulants on 10\% SEO level (Figure 4). 


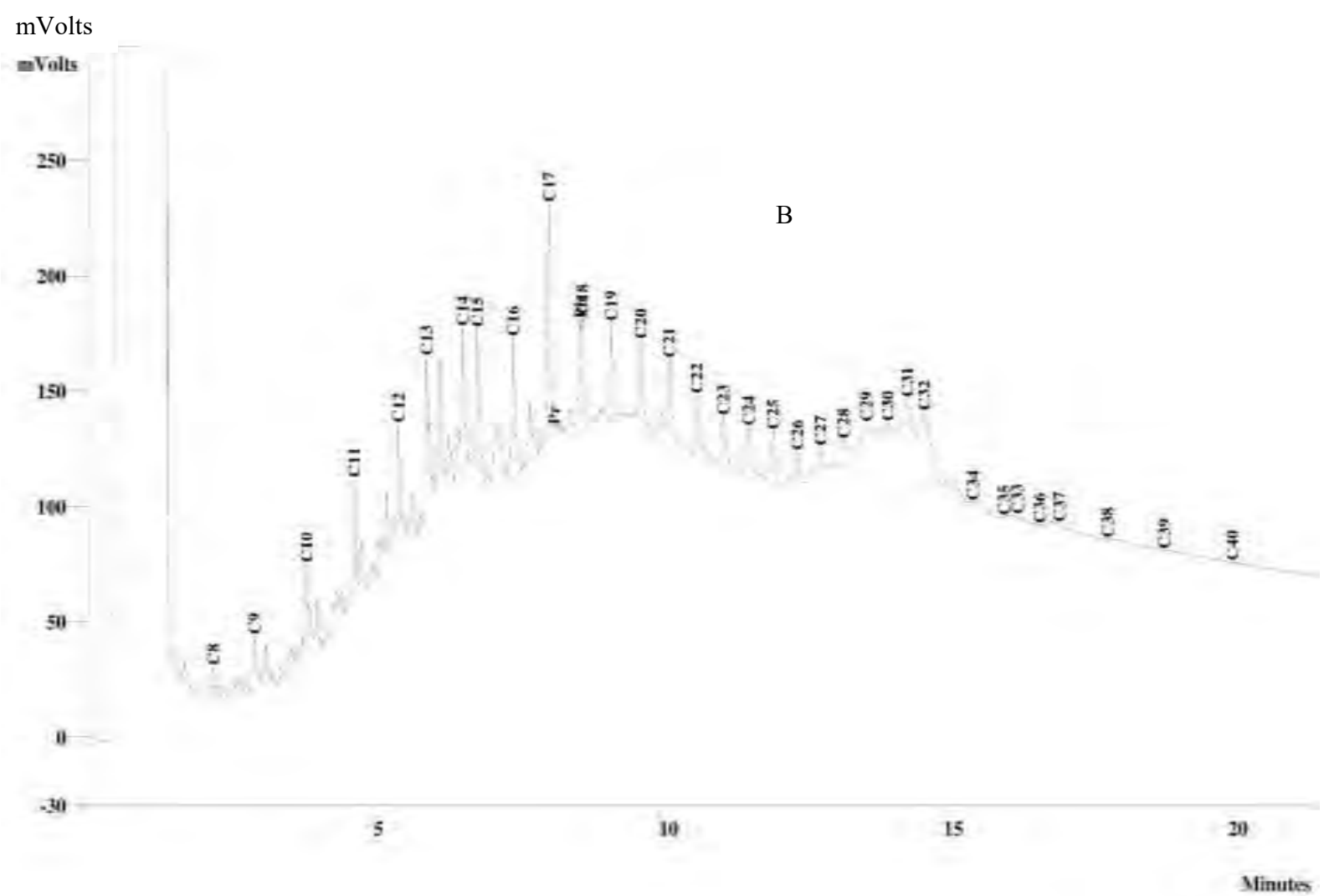

Minutes



Minutes

Figure 1: Chromatograms showing total petroleum hydrocarbon contents of $A$ to represent $5 \%$ spent engine oil (SEO) contaminated soil, $B$ to represent $10 \%$ spent engine oil (SEO) contaminated soil, and $C$ to represent $15 \%$ spent engine oil (SEO) contaminated soil before bacterial degradation 

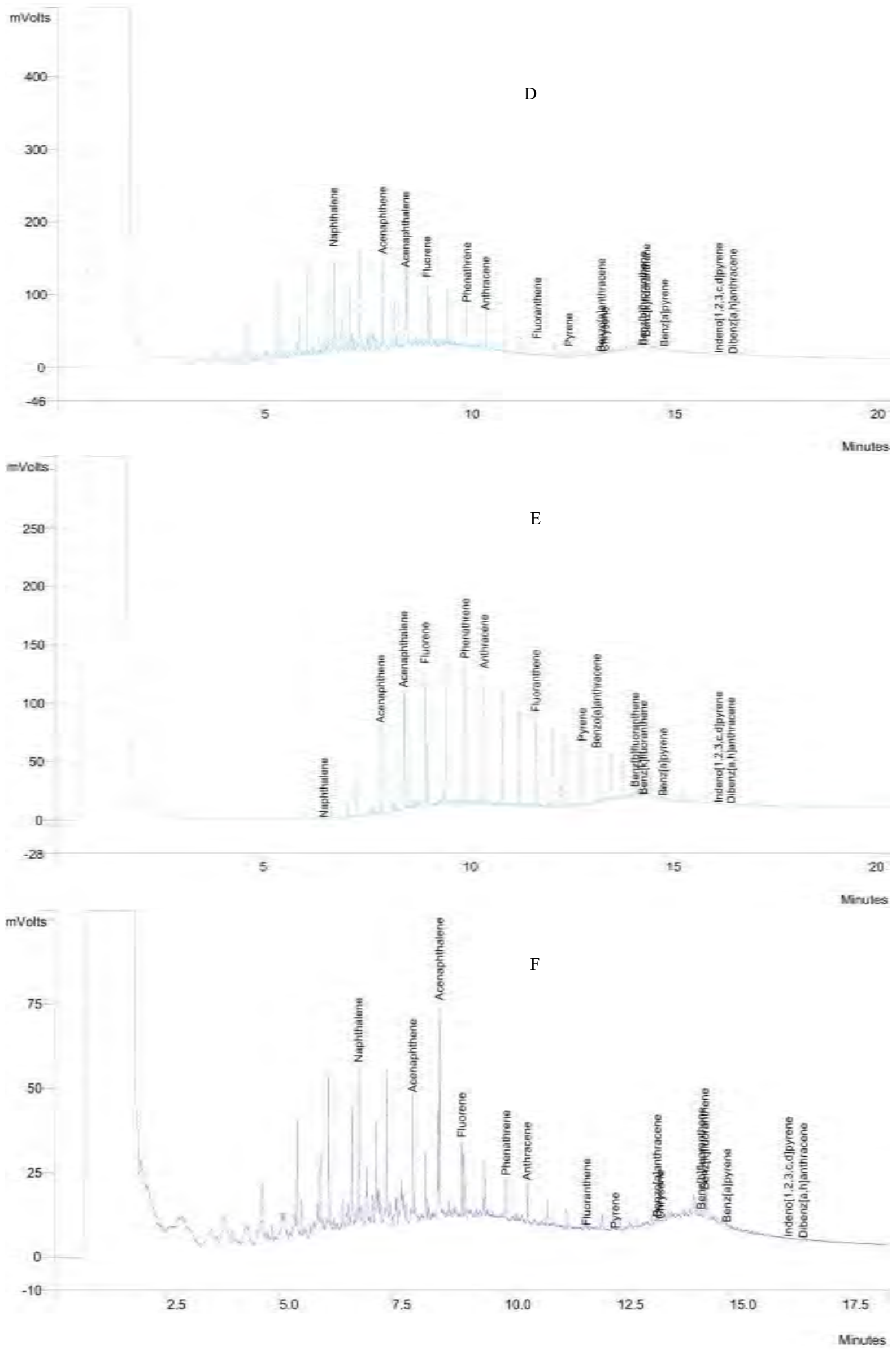

Figure 2: Chromatograms showing polycyclic aromatic hydrocarbon contents of $D$ to represent $5 \%$ spent engine oil (SEO) contaminated soil, $E$ to represent $10 \%$ SEO contaminated soil, and $F$ to represent $15 \%$ SEO contaminated soil before bacterial degradation. Note: Vertical and horizontal axes are as labelled in Figure 1. 


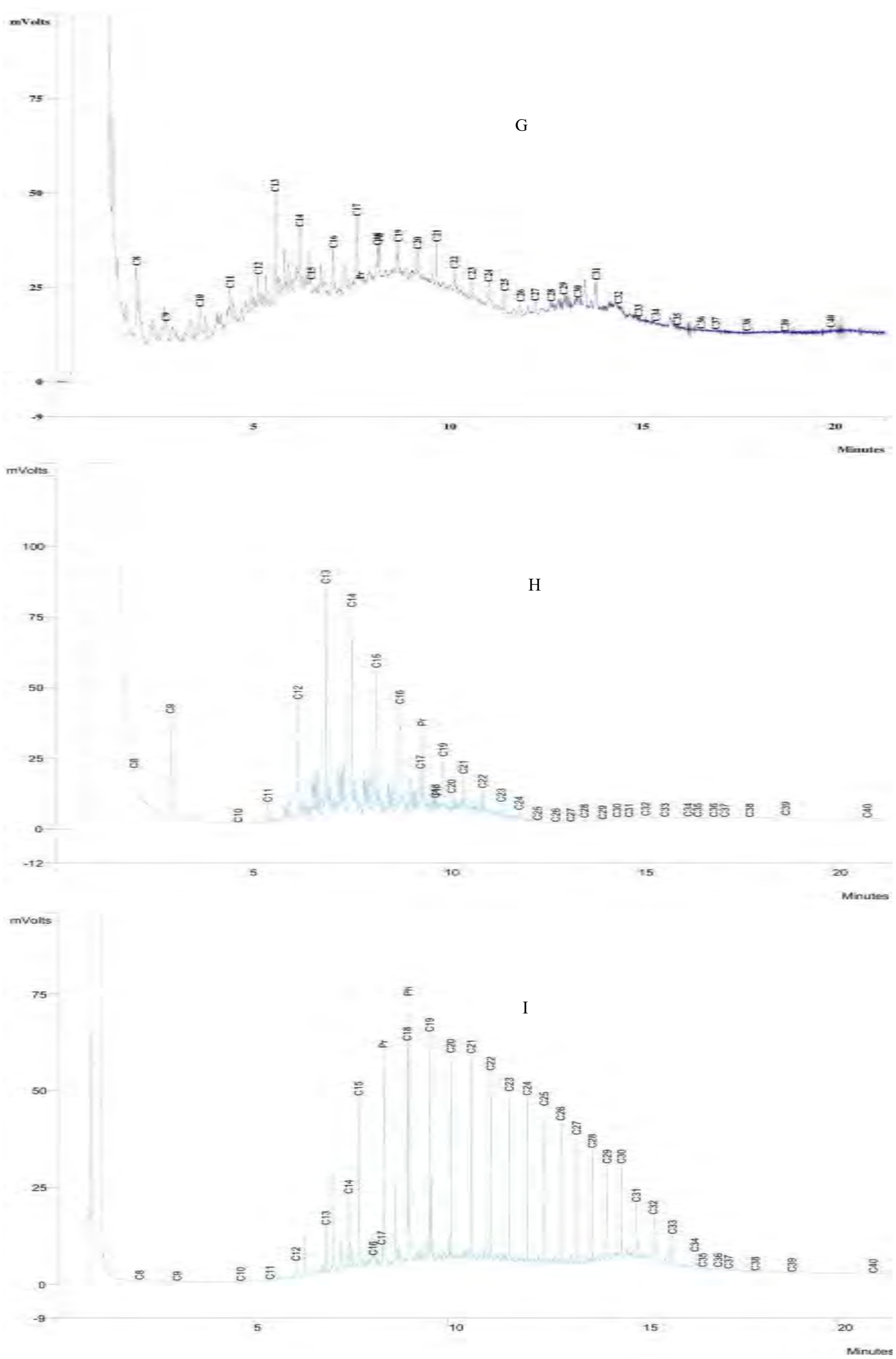

Figure 3: Chromatograms showing degraded total petroleum hydrocarbon fractions due to the Staphylococcus aureus and Bacillus cereus co-culture in the soil amended with compost at the 5th week of incubation, with $G$ representing $5 \%$ spent engine oil (SEO) contamination level, $H$ representing $10 \%$ SEO contamination level, and $I$ representing $15 \%$ SEO contamination level. Note: Vertical and horizontal axes are as labelled in Figure 1. 

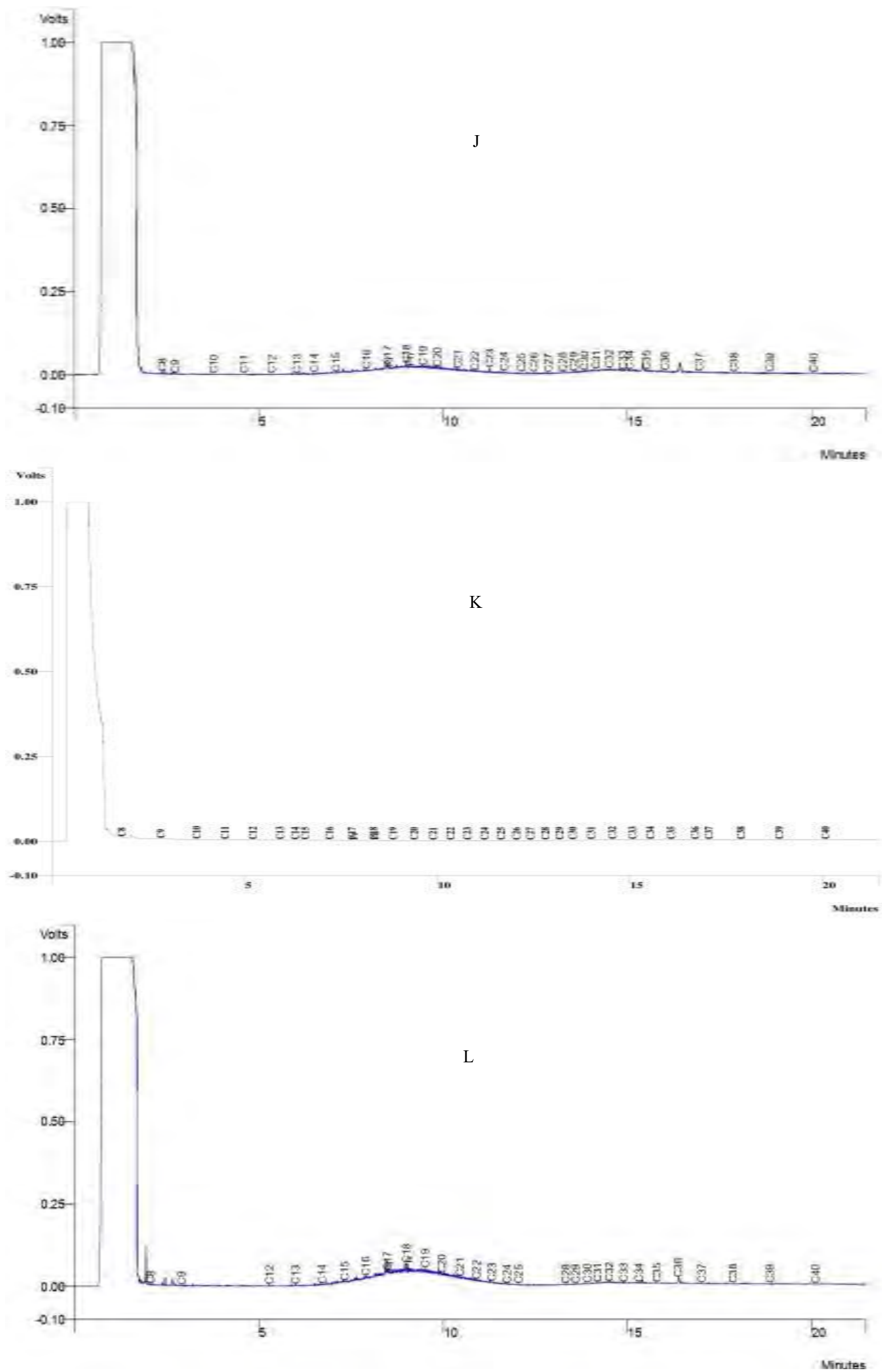

Figure 4: Chromatograms showing degraded total petroleum hydrocarbon fractions due to the Staphylococcus aureus and Bacillus cereus co-culture in the soil at the 10th week of incubation, with $J$ representing $5 \%$ spent engine oil (SEO) contamination level amended with compost, $K$ representing $10 \%$ SEO contamination level amended with powdered cocoa pod husk, and $L$ representing $15 \%$ SEO contamination level amended with compost. Note: Vertical and horizontal axes are as labelled in Figure 1. 
PAHs Biodegradation Potential of Staphylococcus aureus and Bacillus cereus co-culture At the 5th week, the biostimulants significantly $(p<0.05)$ influenced bacterial degradation of PAHs in the SEO-contaminated soil. Compared with other biostimulants, powdered $\mathrm{CPH}$ only enhanced the most degradation (129.1 $\mathrm{mg} \mathrm{kg}^{-1}$ ) aided by Staphylococcus aureus and Bacillus cereus co-

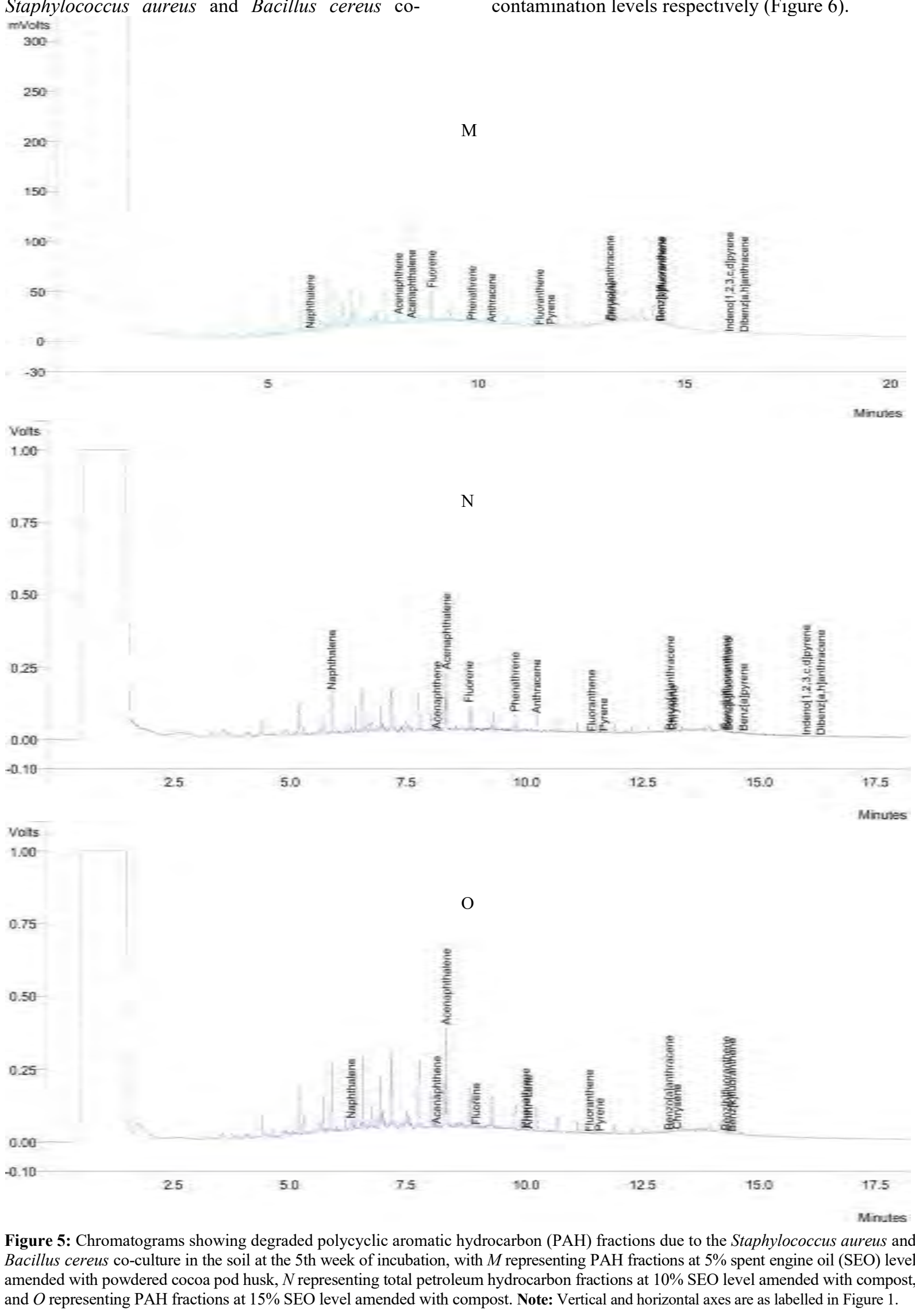

Figure 5: Chromatograms showing degraded polycyclic aromatic hydrocarbon (PAH) fractions due to the Staphylococcus aureus and Bacillus cereus co-culture in the soil at the 5th week of incubation, with $M$ representing PAH fractions at $5 \%$ spent engine oil (SEO) level amended with powdered cocoa pod husk, $N$ representing total petroleum hydrocarbon fractions at $10 \%$ SEO level amended with compost, and $O$ representing PAH fractions at 15\% SEO level amended with compost. Note: Vertical and horizontal axes are as labelled in Figure 1. culture on 5\% SEO contamination level while compost enhanced the most PAHs reductions (92.7 and $157.5 \mathrm{mg} \mathrm{kg} \mathrm{kg}^{-1}$ ) on 10 and $15 \%$ SEO levels respectively (Figure 5). However, at the tenth week, compost enhanced the most reductions (48.8, 39.6 and $94.6 \mathrm{mg} \mathrm{kg}^{-1}$ ) in PAHs compared with other biostimulants on 5,10 and $15 \%$ SEO contamination levels respectively (Figure 6). 

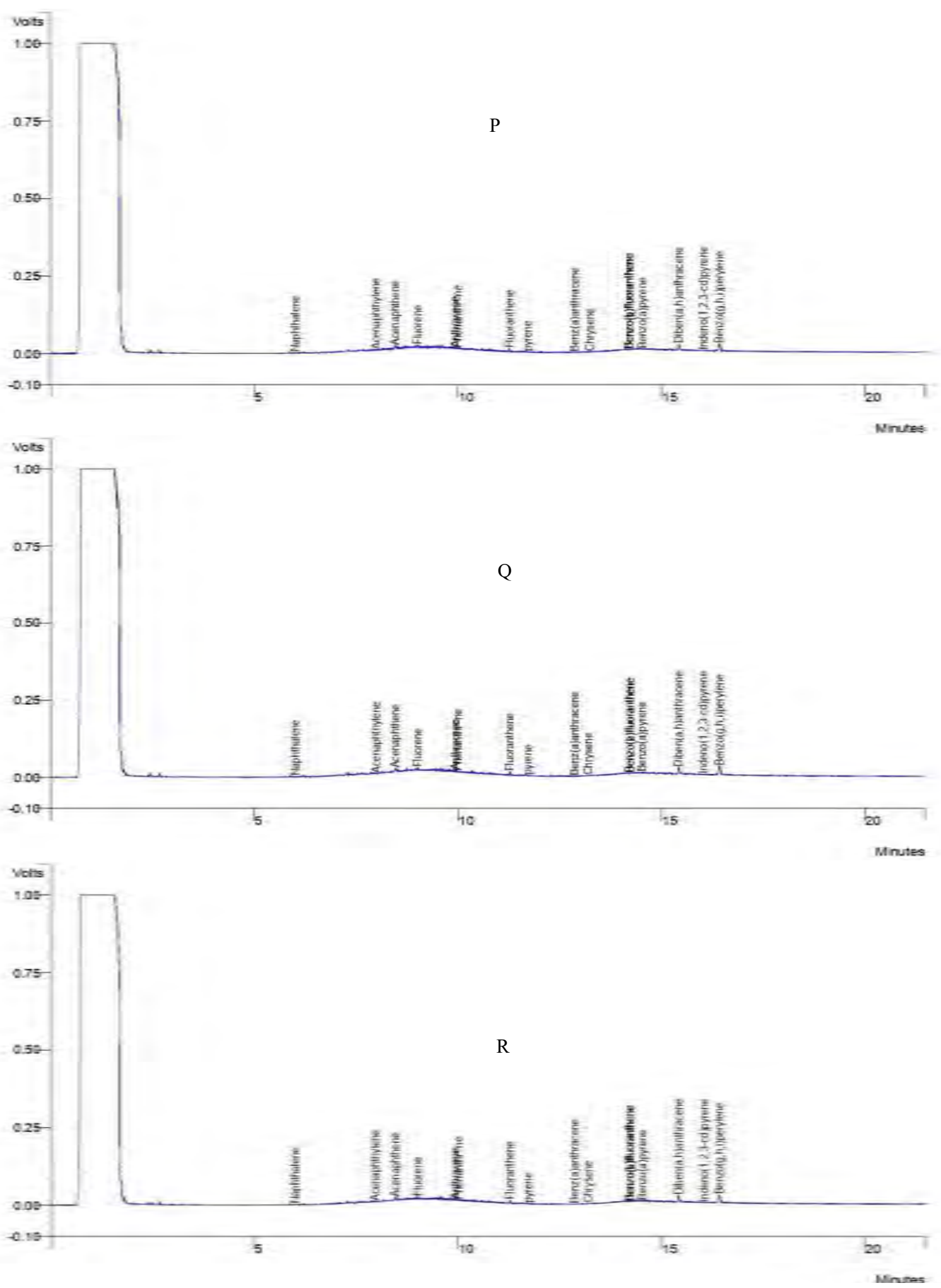

Figure 6: Chromatograms showing degraded polycyclic aromatic hydrocarbon fractions due to the Staphylococcus aureus and Bacillus cereus co-culture in the soil at the 10 th week of incubation, with $P$ representing $5 \%$ spent engine oil (SEO) contamination level amended with compost, $Q$ representing $10 \%$ SEO level amended with compost, and $R$ representing $15 \%$ SEO level amended with compost. Note: Vertical and horizontal axes are as labelled in Figure 1.

\section{DISCUSSION}

The soil employed for the biodegradation assay in this study had C:N ratio of 8.2. This is a very low $\mathrm{C}: \mathrm{N}$ ratio suitable for effective biodegradation of SEO in the soil. Consequently, the addition of biostimulants as a source of nutrients required for bacterial metabolism of the contaminant became imperative. Similar observation and submission has been made by Osaigbovo et al. (2013). The $\mathrm{pH}$ of the soil showed that it is slightly acidic. However, 
$\mathrm{pH}$ obtained from the compost, powdered CD only, and powdered $\mathrm{CPH}$ only ranged from slightly alkaline to alkaline. This alkalinity can be related to the high levels of exchangeable bases, which are characteristic of the biostimulants used in this study. The cation exchange capacity (CEC) of the soil $\left(3.51 \mathrm{cmol} \mathrm{kg}^{-1}\right)$ was very low compared to the biostimulants especially compost $\left(221.70 \mathrm{cmol} \mathrm{kg}^{-1}\right)$ that had the highest value. In reference to Aduayi et al. (2002), this infers that the soil was not fertile enough for any biodegradation assay thus making the addition of biostimulants obligatory.

The assessment of TPH in an environment polluted with petroleum hydrocarbons had been reported by Schwartz et al. (2012). The detection of naphthalene, benzo[a]anthracene, benzo[a]pyrene, fluoranthene and other notable aliphatic and aromatic hydrocarbons in the SEO-contaminated soil samples analyzed in this study is in line with the report of Irwin et al. (1997) and Yerima et al. (2012) on their presence in a typical SEO. The results recorded on the succinct estimations of TPH and PAHs by GC-FID in the soil samples analysed in this study have clearly demonstrated the capability of the instrument to measure such in environmental media containing these petroleum hydrocarbons (Wenning and Martello, 2014; Adeleye et al., 2020).

The significant TPH reductions enhanced by the biostimulation of Staphylococcus aureus and Bacillus cereus co-culture with organic amendment can be attributed to effective supply of nutrients needed for their optimal metabolism and eventual TPH utilization. These results agree with those of Atagana (2008), Yerima et al. (2011), Chikere (2012), Dadrasnia and Agamuthu (2013), Kamaluddeen et al. (2016); Oyedele et al. (2016), regarding the biostimulatory influence of organic amendments in enhancing the ability of microorganisms to attain TPH reductions. The depicted reductions in TPH recorded in this study are in line with the results of Maryam and Ujah (2016) alongside Kawo and Faggo (2017) who reported decrement in the peaks of chromatograms as an indication of bacterial degradation of petroleum hydrocarbons.

The results recorded in this study are in agreement with the submissions of Van Gestel et al. (2003) together with Ling and Isa (2006), about the ability of organic fertilizers to improve soil structure, leading to a diminishing bulk density and lower rate of PAHs volatilization. Again, these results are in concord with the submission of USEPA (1994) regarding the ability of indigenous bacterial communities in contaminated soil to effect faster PAHs degradation when enhanced adequately as their adaptation to such polluted environment would not be hindered. These results are in support of the submission of Pothuluri and Cerniglia (1994) concerning the key role that autochthonous microbial communities play in expunging PAHs from contaminated environments owing to their cost effectiveness and capability to attain complete remediation.
As depicted in the chromatograms, the enhancement of Staphylococcus aureus and Bacillus cereus co-culture with compost and powdered $\mathrm{CPH}$ yielded significant reductions in the PAHs components most especially benzo (a) anthracene known to be very toxic and causing serious health problems. Similar observation regarding the reduction of benzo (a) anthracene using the combination of bacteria and organic amendments has been reported by Yerima et al. (2012). In agreement with the results obtained in this study, Ezenne et al. (2014), equally reported the efficiency of poultry droppings in the removal of TPH and PAHs contents from petroleum hydrocarbon impacted soil in which application rate of the biostimulant and the contaminated site played a vital role in achieving the documented significant removal.

\section{CONCLUSION}

In this study, bacterial degradation of TPH and PAHs was significantly enhanced by the addition of biostimulants in all the SEO contaminated soils at varying contamination levels studied. However, the quantity of SEO degraded was significantly higher in the bioaugmented and biostimulated soil samples compared with the control. The compost generated from the composting of $\mathrm{CPH}$ and $\mathrm{CD}$ and other biostimulants in this study played a significant role in the biodegradation of SEO and can be effectively adopted for the bioremediation of petroleum hydrocarbon related pollution.

ACKNOWLEDGEMENTS The first author (AAO) acknowledges the support received from the management of Federal University Dutse, Nigeria.

CONFLICT OF INTERESTS The authors declare that they have no conflict of interests regarding this study.

\section{REFERENCES}

Abioye O., Agamuthu P. and Abdul-Aziz R. (2012). Biodegradation of used motor oil using organic waste amendment. Biotechnol. Res. Int., (2012), Article ID 587041. Retrieved from: https://downloads.hindawi. com/archive/2012/587041.pdf

Adeleye A., Yerima M., Nkerenwem M., et al. (2020). Enhanced degradation of hydrocarbons in spent engine oil contaminated soil by Pseudomonas aeruginosa and Alcaligenes faecalis. FUW Trends Sci. Technol. J., 5 (2), 437-444

Adeleye A., Yerima M., Nkerenwem M., et al. (2019). Effect of organic amendments on the decontamination potential of heavy metals by Staphylococcus aureus and Bacillus cereus in soil contaminated with spent engine oil. Novel Res. Microbiol. J., 3 (5), 471-484

Aduayi E.A., Chude V.O., Adebusuyi B.A. and Olayiwola S.O. (2002). Fertilizer use and management practices for crops in Nigeria. Federal Ministry of Agriculture and Rural Development Abuja, Nigeria, pp. 63-65

Agbor R.B., Ekpo I.A., Kalu S.E., et al. (2015). Growth pattern of two crop species on bioremediated hydrocarbon polluted soils. Acad. J., 10 (2), 58-63

Atagana H.I. (2008). Compost bioremediation of hydrocarbon-contaminated soil inoculated with organic manure. Afr. J. Biotechnol., 7 (10), 1516-1525

Ayotamuno M.J., Kogbara R.B., Ogaji S.O. and Pobert S.D. (2006). Bioremediation of a crude oil polluted agricultural soil in Port Harcourt Nigeria. Appl. Energy, 83, 1249-1257 
Badr El-Din S.M., Moussa T.A., Moawad H. and Sharaf O.A. (2014). Isolation and characterization of polyaromatic hydrocarbons degrading bacteria from compost leachate. J. Adv. Biol., 5 (2), 651-660

Bhattacharyya J.K. and Shekdar A.V. (2003). Treatment and disposal of refinery sludges: Indian scenario. SAGE J., 21 (3), 249-261

Chikere C.B. (2012). Culture-independent analysis of bacterial community composition during bioremediation of crude oil-polluted soil. Brit. Microbiol. Res. J., 2 (3), 187-211

Chorom M., Sharifi H. and Motamedi H. (2010). Bioremediation of a crude oil polluted soil by application of fertilizers. Iranian J. Environ. Health Sci. Eng., 7 (4), 319-326

Clemente A.R., Anazawa T.A and Durrant L.R. (2001). Biodegradation of polycyclic aromatic hydrocarbons by soil fungi. Braz. J. Microbiol., 32 (4), 255-261

Dadrasnia A. and Agamuthu P. (2013). Potential biowastes to remediate diesel-contaminated soils. Global NEST J., 15 (4), 474-484

Dean-Ross D., Moody J. and Cerniglia C. (2002). Utilization of mixtures of polycyclic aromatic hydrocarbons by bacteria isolated from contaminated sediment. FEMS Microbiol. Ecol., 41 (1), 1-7

Dinkla I.J., Garbo E.M. and Janssen D.B. (2001). Effects of iron limitation on the degradation of toluene by Pseudomonas strains carrying the TOL (WWO) plasmid. Appl. Environ. Microbiol., 67 (8), 3406-3412

Ezenne G.I., Nwoke O.A., Ezikpe D.E., Obalum S.E. and Ugwuishiwu B.O. (2014). Use of poultry droppings for remediation of crude-oil-polluted soils: Effects of application rate on total and poly-aromatic hydrocarbon concentrations. Int. Biodeter. Biodegrad., 92, 57-65

Irwin R.J., Van-Mouwerik M., Stevens L., Seese M.D. and Basham W. (1997). Environmental Contaminants Encyclopedia. National Park Service, Water Resour. Div., Fort Collins, Colorado. Accessed 05/11/2017 https: //www.nature.nps.gov/water/ecencyclopedia/index.cfm

Kamaluddeen K., Yerima M., Abu T. and Deeni Y. (2016). Biostimulatory effect of processed sewage sludge in bioremediation of engine oil contaminated soils. Int. J. Sci. Technol. Res., 5 (2), 203-207

Kawo A.H. and Faggo A.A. (2017). Enhanced removal of crude oil in soil by co-culture of Bacillus subtilis and Pseudomonas aeruginosa isolated from contaminated soil in Kano State, Nigeria. Bayero J. Pure Appl. Sci., 10 (1), 423-427

Komolafe A.F., Adejuyigbe C.O., Babalola O.A., Soretire A.A. and Kayode C.O. (2021). Fertilizer values of composts as affected by plant materials and composting duration on maize (Zea mays) performance. Agro-Science, 20 (1), 87-94

Ling C.C. and Isa M.H. (2006). Bioremediation of oil sludge contaminated soil by co-composting with sewage sludge. J. Sci. Ind. Res., 65, 364-369

Maiti A., Das S. and Bhattacharyya N. (2012). Isolation and characterization of a new bacterial strain from petroleum oil contaminated soil. Indian J. Sci., 2 (2), 103-108

Maryam L.R.S. and Ujah U.J.J. (2016). Ethanol removal of crude oil in soil by mixed culture of Bacillus megaterium UL05 and Pseudomonas aeruginosa UL07. Int. J. Environ. Bioremed. Biodegrad., 4 (1), 8-12

Nkereuwem M., Adeleye A.O., Edem I., et al (2020). Response of indigenous microbial community to drying-rewetting stress: Evidences from Warwade Dam irrigation scheme soil in Dutse, Jigawa State. Dutse J. Agric. Food Security, 7 (1), 55-64

Obi L.U., Atagana H.I. and Adeleke R.A. (2016). Isolation and characterisation of crude oil sludge degrading bacteria. Springer Plus, 5, 1946
Ogunbayo A., Bello R. and Nwagbara U. (2012). Bioremediation of engine oil contaminated site. $J$. Emerg. Trends Eng. Appl. Sci., 3 (3), 483-489

Osaigbovo A.U., Law-Ogbomo K.E. and Agele S.O. (2013). Effects of spent engine oil polluted soil and organic amendment on soil chemical properties, micro-flora on growth and herbage of Telfairia occidentalis (Hook F). Bayero J. Pure Appl. Sci., 6 (1), $72-78$

Oyedele A., Ebinowen Y., Fapojuwo O., Daramola B. and Ayoko O. (2016). Bioremediation of crude oil polluted soil: Maize husk compost as a test bioremediant. Pharm. Chem. J., 3 (2), 254-261

Panda S., Kar R. and Panda C. (2013). Isolation and identification of petroleum hydrocarbon degrading microorganisms from oil contaminated environment. Int. J. Environ. Sci. Technol., 3 (5), 1314-1321

Pothuluri J.V. and Cerniglia C.E. (1994). Microbial metabolism of polycyclic aromatic hydrocarbons. In: Chaudry G.R. (ed.), Biological Degradation and Bioremediation of Toxic Chemicals (pp. 92-124). Chapman \& Hall, London

Schwartz G., Ben-Dor E. and Eshel G. (2012). Quantitative analysis of total petroleum hydrocarbons in soils: Comparison between reflectance spectroscopy and solvent extraction by 3 certified laboratories. Appl. Environ. Soil Sci., (2012). Retrieved from: https:// www.hindawi.com/journals/aess/2012/751956/

Soretire A.A., Oshiobugie A.A., Thanni B.M., Balogun S.A. and Ewetola J.M. (2017). Bioremediation of soil contaminated with crude oil using fresh and decomposed animal manure. Nig. J. Biotechnol., 34, 12-18

Umana S.I., Uko M.P., Bassey M.P. and Essien J.P. (2017). Hydrocarbons degrading potential of stimulated cultures of bacteria isolated from humic fresh water sediment of Eniong River in the Niger Delta of Nigeria. Microbiol. Res. J. Int., 21 (3), 1-13

Umoren A.S., Igwenagu C.M., Ezeaku P.I., et al. (2019). Long-term effects of crude oil spillage on selected physicochemical properties including heavy metal contents of sandy tropical soil. Bulletin Environ. Contamination Toxicol., 102, 468-476

USEPA (1994). Land farming: Chapter 5. United State Environmental Protection Agency, Washington, DC. Retrieved 20/09/2019 from https://www.epa.gov/sites/ production/files/2014-03/documents/tum ch5.pdf

USEPA (2003). Method 8015C (SW-846): Non-halogenated organics using GC/FID: Revision 4. US Environ. Protection Agency, Washington, DC. Retrieved 20/09/2019 from https://www.epa.gov/esam/epa-method-8015dsw-846-nonhalogenated-organics-using-gc

Van Gestel K., Mergaert J., Swings J., Coosemans J. and Ryckeboer J. (2003). Bioremediation of diesel oilcontaminated soil by composting with biowaste. Environ. Pollut., 125, 361-368

Wang X., Chi C., Nie Y., et al. (2011). Degradation of petroleum hydrocarbons (C6-C40) and crude oil by a novel Dietzia strain. Bioresour. Technol., 102 (17), 7755-7761

Wenning R. and Martello L. (2014). Environmental forensics for persistent organic pollutants. In: POPs in Marine and Freshwater Environments (Chap. 8, pp. 357-390). https://www.science direct.com/science/ article/pii/B9780444594242000086?via\%3Dihub

Yerima M., Agina S., Umar A., et al. (2013). Bacterial degradation of crude oil components using brewery effluents as biostimulation agents. Vivechan Int. J. Res., 4, 10-17

Yerima M., Agina S., Zuru A., et al. (2011). Assessment of biostimulation using some organic wastes in bacterial reclamation of crude oil contaminated agricultural soil. J. Sustain. Dev. Environ. Protect., 1 (1), 69-76

Yerima M.B., Umar A.F., Shinkafi S.A. and Ibrahim M.L. (2012). Bioremediation of hydrocarbon pollution: A sustainable means of biodiversity conservation. $J$. Sustain. Dev. Environ. Protect., 2 (3), 43-50 